\title{
Rare Occurrence of Mirabilite in the Thirteenth-Century Historic Salt Mine in Bochnia (Poland): Characterisation, Preservation, and Geotourism
}

\author{
Aleksandra Puławska ${ }^{1,2}$ (D) Maciej Manecki $^{1}$ (D) Michał Flasza $^{2}$ (D) $\cdot$ Edyta Waluś $^{1} \cdot$ Karolina Wojtowicz $^{1}$
}

Received: 3 July 2020 / Accepted: 8 April 2021 / Published online: 15 April 2021

(C) The Author(s) 2021

\begin{abstract}
The small stalactites found on the ceiling at level I near the Sutoris shaft in the thirteenth-century historic salt mine in Bochnia, Poland, are mainly composed of mirabilite $\left(\mathrm{Na}_{2} \mathrm{SO}_{4} \cdot 10 \mathrm{H}_{2} \mathrm{O}\right)$ followed by blödite $\left(\mathrm{Na}_{2} \mathrm{Mg}\left(\mathrm{SO}_{4}\right)_{2} \cdot 4 \mathrm{H}_{2} \mathrm{O}\right)$. The unique presence of these two minerals in only one location in this old underground mine is attributed to contemporary precipitation from percolating solutions. This can be caused by a combination of at least two factors: a specific and stable microclimate (characterised by a low temperature, high humidity, and relatively strong air circulation which accelerates the processes of evaporation and crystallisation) and the specific chemical composition of the leaking solution (contains a low carbonate and high sulphate content, and characterised by acidic $\mathrm{pH}(4.8)$ and intermediate-mineralisation $(174,308 \mathrm{mg} / \mathrm{L}))$. The microclimate specified above can be linked to the long distance from the ventilation shaft that pumps the air from the surface to the mine, while the composition of the leaking solution as well as the hydrochemical modelling results obtained with PHREEQC can be directly related to the top anhydrite layer and the overlying secondary cap consisting mainly of claystone, anhydrite, and gypsum. In this study, the challenges underlying the preservation of mirabilite in the underground environment of the salt mine are discussed, in terms of both nature and mining law. Based on the results of detailed geological, mineralogical, and chemical research, appropriate solutions that can be practically applied for the management, preservation, and protection of the mirabilite efflorescence are proposed. The presence of this intriguing mineral, with appropriate protection, can be another geological attraction for tourists visiting this thirteenth-century UNESCO-recognised salt mine.
\end{abstract}

Keywords Mirabilite $\cdot$ Efflorescence $\cdot$ Sodium sulphate $\cdot$ Blödite $\cdot$ UNESCO World Heritage $\cdot$ Geoconservation

\section{Introduction}

Mirabilite, also known as Glauber's salt, is a hydrous salt of sodium sulphate $\left(\mathrm{Na}_{2} \mathrm{SO}_{4} \cdot 10 \mathrm{H}_{2} \mathrm{O}\right)$. This is a relatively rare mineral that forms under certain conditions through the evaporation of brines rich in $\mathrm{Na}$ and $\mathrm{SO}_{4}$. It is found in the sodium sulphate deposits in the Northern Great Plains of Canada, on the surface of playa lakes in Central and Northeast Spain and on the dry

Aleksandra Puławska

alexpulawska@gmail.com

1 Department of Mineralogy, Petrography and Geochemistry, Faculty of Geology, Geophysics and Environmental Protection, AGH University of Science and Technology, Al. Mickiewicza 30, 30-059 Kraków, Poland

2 Bochnia Salt Mine, ul. Campi 15, 32-700 Bochnia, Poland shores of the Aral Sea (Valero-Garcés et al. 2000; Kelley and Holmden 2001; Crétaux et al. 2009; Cabestrero et al. 2018). However, the crystallisation of mirabilite due to the moisture present in the pores in masonry is regarded as a harmful process resulting from salt precipitation on building materials (RuizAgudo et al. 2007; Marszałek et al. 2019). It has been identified that the precipitation of mirabilite and other similar salts is provoked by the freezing processes that occur in the glacial or subglacial bodies of water in Antarctica (Liu et al. 2015). In recent years, the hydrated sulphates of magnesium and sodium as well as their phase transition processes have been intensively studied because it is considered that their presence can indicate the availability of water on the surface of other planets (Vaniman et al. 2004; Dalton III and Pitman 2012; De Waele et al. 2017; Rapin et al. 2019).

The contemporary findings of rare mirabilite precipitates in caves and underground excavations are quite attractive and 
may become the subject of interest in a special sector of tourism-geotourism. Since most geological processes and phenomena take place under the surface of the earth, openaccess subterranean objects, which are natural or man-made, are commonly considered to offer a unique geological experience to the visitors (Garofano and Govoni 2012; Liso et al. 2020). Mirabilite efflorescence is a manifestation of both leaching of chemical components from the rock mass by circulating water and secondary precipitation of minerals. Therefore, the occurrence of rare minerals in an underground system, as a result of recent evolution, can increase its geodiversity, and consequently further strengthen the geotourism potential.

Mirabilite precipitates have been described in the Murra-elelevyn Cave in Western Australia, in the Mammoth Cave in the USA, in the Gamslöcher-Kolowrat Cave in Austria, and in the Gortani Cave in Italy (Bridge 1973; Kennedy and Watson 1997; Bieniok et al. 2011, Forti 2017). In Poland, the occurrence of mirabilite was first reported in 1971 in the historic underground salt mine in Wieliczka (Wiewiórka 1971); however, this part of the mine is not accessible to the public (d'Obyrn 2012). In 2014, similar efflorescences and encrustations were identified in the old underground salt mine in Bochnia, Poland (Dudek et al. 2014). Nevertheless, its potential for geotourism development, as well as the protection and conservation of this rare mineral, has not been well researched. This requires immediate investigation since mirabilite is an unstable mineral and exhibits a strong tendency to undergo dehydration and transition to a more stable anhydrous phase called thenardite $\left(\mathrm{Na}_{2} \mathrm{SO}_{4}\right)$. Such transition can be induced by changes in temperature and relative humidity $(\mathrm{RH})$ of the surrounding environment. Therefore, only thenardite has been pointed out as the predominant sodium sulphate in the geological records (Ortí et al. 2002; Herrero et al. 2015), which makes the recent finding of mirabilite in the Bochnia Salt Mine even more interesting and valuable.

The salt mines of Bochnia and Wieliczka, both of which are located in southern Poland near Kraków, belong to the thirteenth century. These famous historic mines are recognised as the UNESCO World Heritage Sites and operate as tourist destinations. The deposit exposed in these mines comprises salt-rich strata belonging to an evaporite succession that originated in the Carpathian Foredeep in an epicontinental sea, which existed between the Early Oligocene and late Middle Miocene (Peryt 2013). In response to the growing public interest focused on exploring the natural and raw interior of the mine, intensified efforts have been made in Bochnia Salt Mine in the last two decades to ensure that mine workings of high geological value are available to the tourists. In general, old mines are considered excellent sites for fieldwork in earth science education (López-García et al. 2011; Madziarz 2013; Hellqvist 2019). For this reason, a total of 27 interesting geological outcrops of the Bochnia salt deposit have already been brought under legal protection, with the relevant locations labelled as documentary sites. However, many secondary geological formations, resulting from natural phenomena induced by human activities, are yet to be subjected to legal protection.

This work focuses on the mineralogical characteristics of mirabilite efflorescence recently discovered in the Bochnia underground salt mine as well as the preservation of this fragile and unstable mineral in the mine. Adaptation of the mirabilitic site for tourism is in line with the current trend of interdisciplinary integration of the tourist offer currently provided by the mine (based more on the history of industry) with a particular emphasis on geological heritage. Since this underground mine is open to tourists, it is highly important to ensure that this rare mineral is conserved and legally protected. Despite general knowledge about the formations of mirabilite, there remains a need to understand the challenges underlying the conservation and protection of such fragile mineral in an underground mine, including the form of protection within the legal system - both nature and mining law - and the adaptation of such demanding environment for tourism.

\section{Description of the Bochnia Salt Mine}

\section{Tourist Attraction}

The beginning of rock salt mining in Bochnia dates back to the first half of the thirteenth century. Salt production in the Bochnia Salt Mine ended in 1990. Rock salt mining lasted almost 750 years in the mine, which makes it a unique natural and technical monument in the world, which presents all the historical developmental stages of the mining industry from the thirteenth to the twentieth century (UNESCO 2013). At the same time, mining work carried out over these years has exposed the interesting geological features of the deposit.

After the end of its industrial operations, the Bochnia Salt Mine focused on tourism and recreation. At the beginning of the 1990s, the first tourists visited the mine under the supervision of the miners. Initially, only around 1500 tourists visited the mine each year. Since 1995, the tourist traffic has been effectively organised and supervised by professional guides. This, together with the adaptation of additional corridors for the purpose of tourism, resulted in a steady increase in the number of visitors. In 2000 , about 90,000 people visited the mine. Then, the most valuable and unique mine workings were gradually opened to the public. The adaptation works led to the discovery of interesting geological structures and valuable remnants of historic excavations. The present extensive spatial structure of the historic mine consists of nine mine galleries constituting a total length of about $60 \mathrm{~km}$ (Wiewiórka et al. 2009). A significant part of the excavations is included in the tourist trails (Puławska et al. 2021). In 2017, 
the number of tourists visiting the Bochnia mine exceeded 190,000 and has remained at a high level since then.

Currently, the mine has a very wide tourist offer. The visitors can choose from three different tourist routes, including an underground multimedia exhibition. Due to the unique microclimate in the salt excavations, overnight stays and accommodation as well as special events are also organised in the mine (Fig. 1).

With the view of increased interest in nature tourism, the Bochnia Salt Mine focuses on interdisciplinary integration of the current tourist offer (based more on the history of industry) with a particular emphasis on geological heritage. It is well known that the presence of appropriate geosites, combined with other tourist attractions, may significantly increase the number of tourists visiting a given area (Gordon 2018). Therefore, a new tourist route called 'Nature Route' was created in 2016 by extending the existing route to include the geological significance of the mine and exposed minerals forming the salt deposits. The growing public interest in exploring the natural and raw interior of the mine also prompted the idea of opening an additional route that leads to the oldest pits from levels I to IV.

\section{Protection and Conservation of Natural and Cultural Heritage}

The Bochnia Salt Mine was first listed as a local monument in 1981. In 2000, it was recognised as a National Historical Monument, which prevented its liquidation. At the beginning of the twenty-first century, intensive efforts were made to ensure that mine workings of high geological value are available to the tourists. The original damaged excavations of the mine and the mining corridors were cleaned, an appropriate drainage system was installed, ceilings and side walls of the mine were secured with wooden supports and anchors, the airflow system was adjusted, and communication routes were reconstructed. To preserve the geological heritage exposed in mining excavations for future generations, 27 areas of geologically valuable salt deposit have been taken under legal protection as 'documentary sites' since 2005 (Wiewiórka et al. 2008). Thirteen of these areas are located on the tourist trails, while access to the remaining 14 unique geological objects is restricted for safety reasons and requires special consent and supervision. Each documentary site carries an information board that explains its geological features (Fig. 2). The
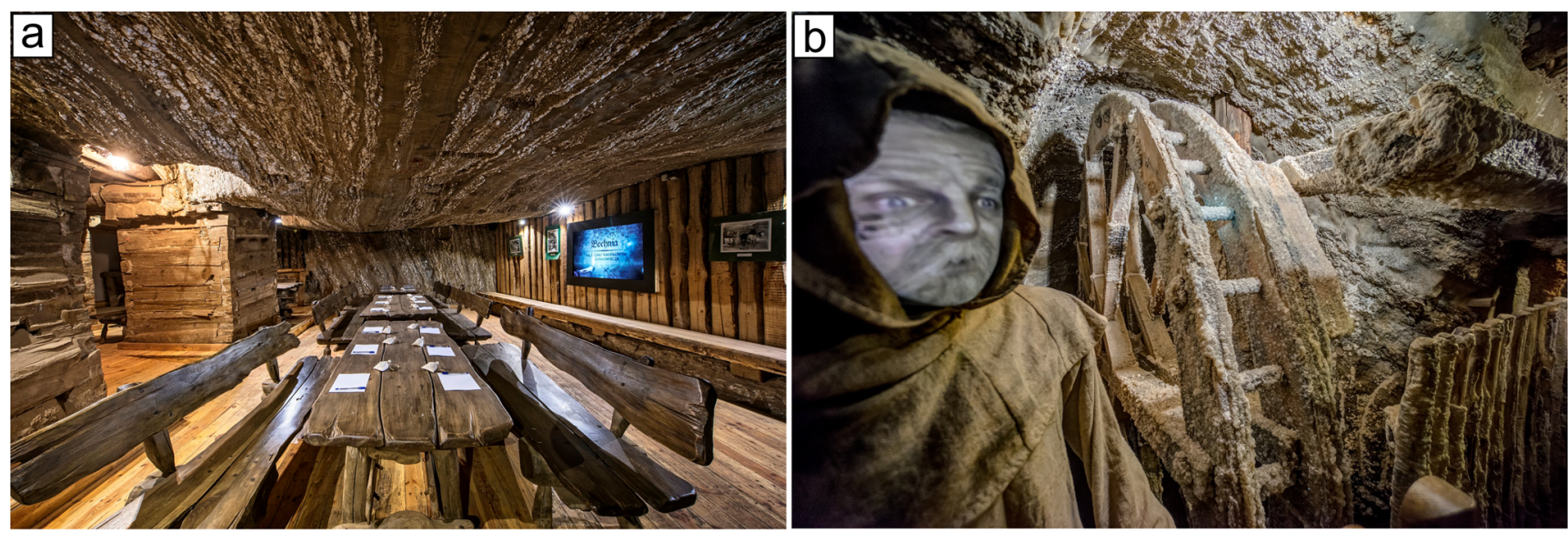

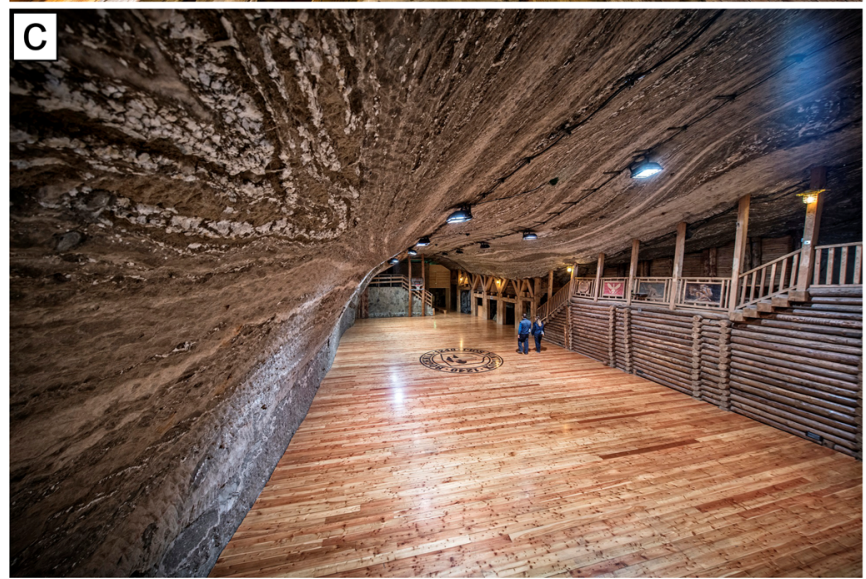

Fig. 1 Examples of the use and adaptation of old mining excavations to tourist activities in the Bochnia Salt Mine. a A multimedia display in a former horse stable. b A multimedia display integrated with a historic

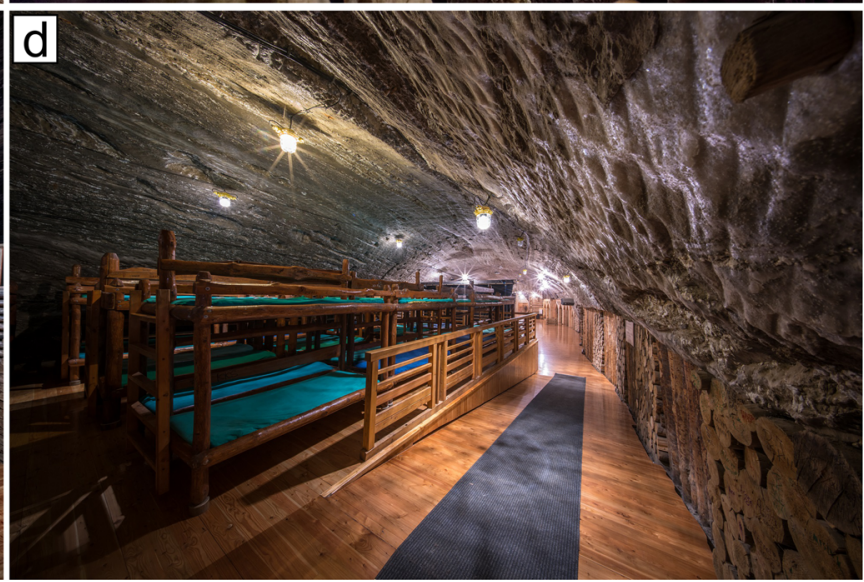

water wheel. c A basketball court. d A bedroom with 250 seats (photos: Adam Brzoza) 

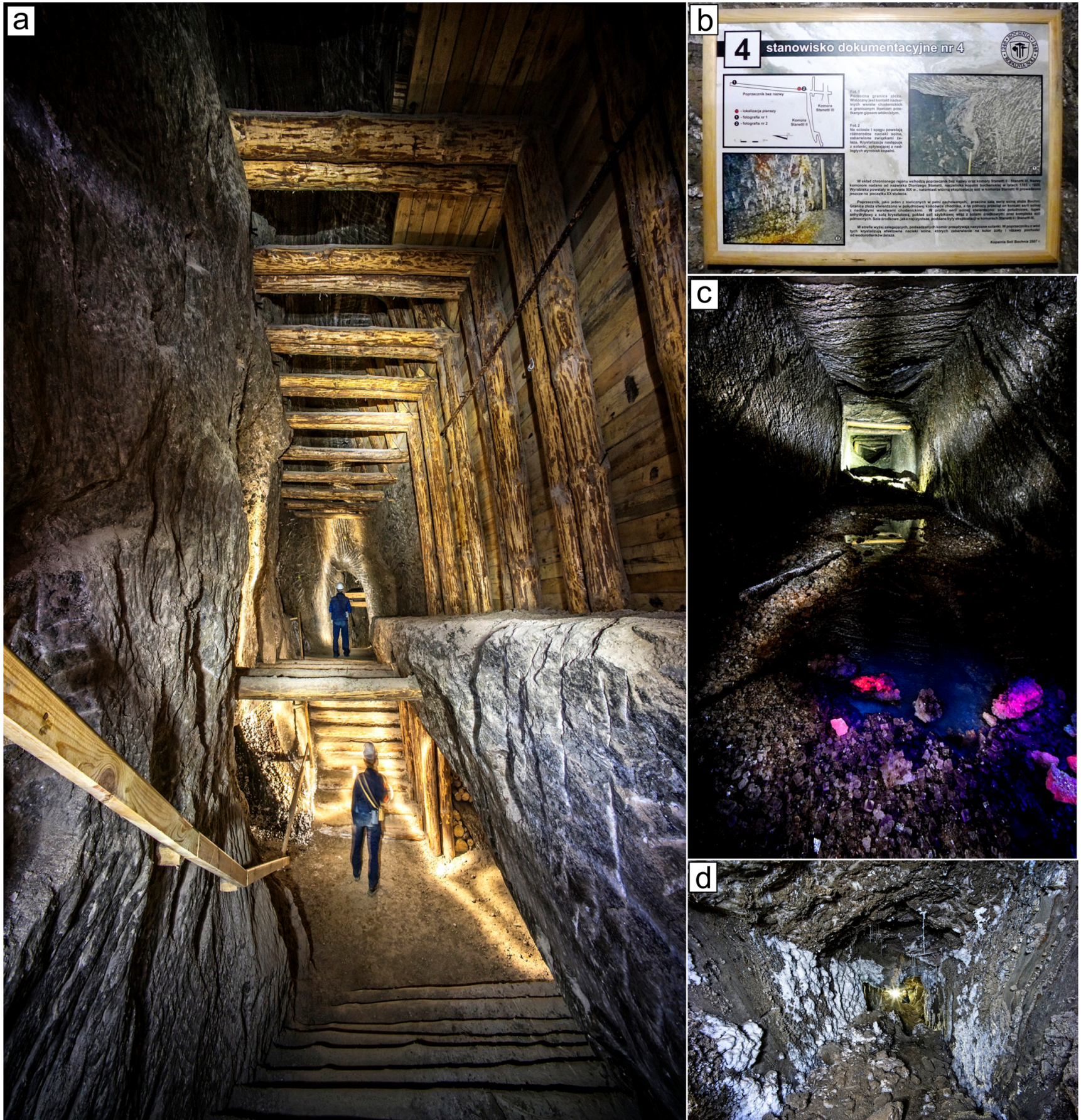

Fig. 2 a Documentary site comprising the Stanetti Chamber (level II); its narrow and high shape result from the characteristic steep layers of middle salts located in the higher parts of the deposit. b An example of a geological information board. $\mathbf{c}$ The occurrence of fluorescent halite,

adaptation works undertaken for the opening of the new tourist routes will enable safe access to three of the 14 difficult-toaccess documentary sites (Fig. 2). The new route will start with the Sutoris shaft up to level I, leading through the place where the mirabilite efflorescence is located.

The legal recognition of the historical and natural heritage was a milestone in the inclusion of the Bochnia Salt Mine in which will soon be made available to the tourists as a geological attraction. d An example of level III documentary site comprising northern salts (photos: Adam Brzoza)

the UNESCO World Heritage List in 2013 (as an extension of the entry of the nearby Wieliczka Salt Mine in 1978). Situated close to each other, both mines were worked since the thirteenth century until the late twentieth century, constituting one of the first and most important European industrial operations of those times (UNESCO 2013). Apart from their wellrecognised cultural heritage, the salt mines of Bochnia and 
Wieliczka have specific characteristics due to their geodiversity and are thus being considered for a UNESCO Geopark (Alexandrowicz and Alexandrowicz 2004; Alexandrowicz et al. 2009; Alexandrowicz and Miśkiewicz 2016). These two mines offer a unique and complementary experience to the visitors.

\section{Challenges for Mirabilite Preservation in the Underground Space of the Salt Mine}

The presence of such a rare and intriguing mineral can significantly enhance the image of the mine as a geotourist facility. The unique geological and educational value of this geosite could allow extending the existing network of protected documentary sites in the Bochnia Salt Mine. Moreover, the growing number of documentary sites in the mine will consequently increase its geodiversity. The data available in the documentation sites may later be used in applications for the nomination of Polish Geoparks.

However, due to the Geological and Mining Law which states that the safety of people underground should be ensured, interesting geological excavations cannot always be left exposed. Several documentary sites or exposures have to be covered with the use of mining supports due to poor geomechanical properties of the rocks posing a risk of collapse. The protected outcrops shall not be destroyed, but must at least be partially covered if necessary. For these reasons, the existing legal system of nature conservation is only partially applicable to the protection and preservation of the newly discovered mirabilite precipitates. This might also be relevant to other emerging geosites in Poland (Głowacki 2019). It is obvious that only an easily accessible and visible display of mirabilite stalactites can serve the purposes of education and tourism. Therefore, an individual approach is needed to develop an appropriate practical solution for the preservation and protection of mirabilite stalactites. As specific environmental conditions are required for the crystallisation of mirabilite in underground excavations, the preservation of these fragile minerals seems to be dependent on the attitude and awareness of the mine management than solely on the nature of the protection system.

This suggests that detailed geological, mineralogical, and chemical knowledge of the formation of mirabilite may be essential to propose guidelines on the management and conservation of such rare mineralogical objects in an underground space.

\section{Geological Setting}

The Bochnia salt deposit represents a fragment of the marine sediments of the Miocene salt-bearing formation. It is located in the southern part of the Carpathian Foredeep (Fig. 3).

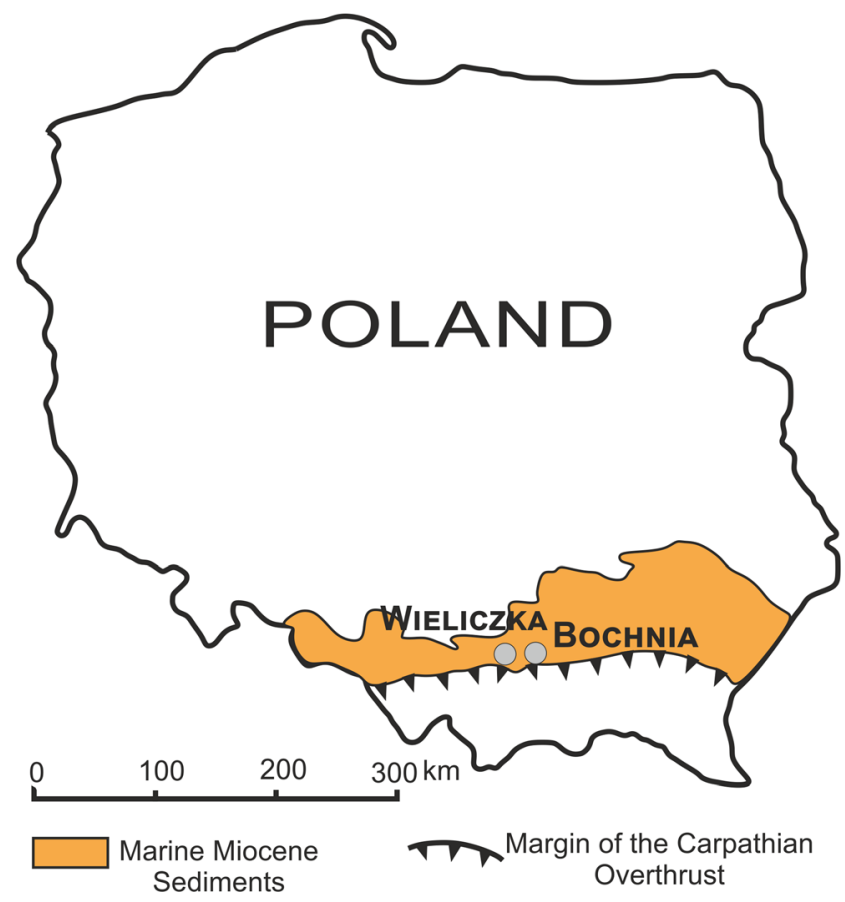

Fig. 3 The extent of Miocene marine deposits in Poland (after Garlicki 2008; modified)

Studies have reported that the uplift of the Carpathians in the Late Miocene resulted in the folding, local tectonic thickening, and uplifting of the Badenian evaporites (Poborski 1952; Garlicki 1979). The Miocene salt-bearing formation primarily consists of the Skawina Beds, the series of evaporites with salt deposit, and the Chodenice Beds (Fig. 4). The Skawina Beds have a thickness ranging from a few metres to $150 \mathrm{~m}$ and contain marly claystone and marly clayey shales, while the Chodenice Beds are 100- to 1000-m thick and are composed of sandy, marly, and clayey shales (Garlicki 2008).

The local accumulation of salt is caused by large-scale folding. In Bochnia, two principal folds have been recognised (Fig. 4a), of which the main one is called the Bochnia Anticline. The salt mine is located in the northern limb of this fold, while the second fold called the Uzbornia Anticline is to the south. The axial parts are dominated by the flysch formations, and the Badenian salt-bearing formations can be seen on the limbs of the folds. Halite is mostly present in the Bochnia Anticline, while the Uzbornia Hill predominantly consists of sulphate evaporites, including alabaster and fibrous gypsum.

The tectonically uplifted Bochnia salt deposit underwent destructive corrosion in the past. Subsequently, during the Pleistocene, the salt-bearing formation was covered by loess and clays. At the top portion of the deposit where the salt was eroded, a clay-gypsum cap was formed (Poborski 1952; Wiewiórka et al. 2008). The evaporite series of the Bochnia deposit is represented by rock salt comprising claystone, anhydrite, mudstone, and zuber interbeds. The overall thickness of the deposit is estimated at approximately $70 \mathrm{~m}$ (Fig. 4b). 


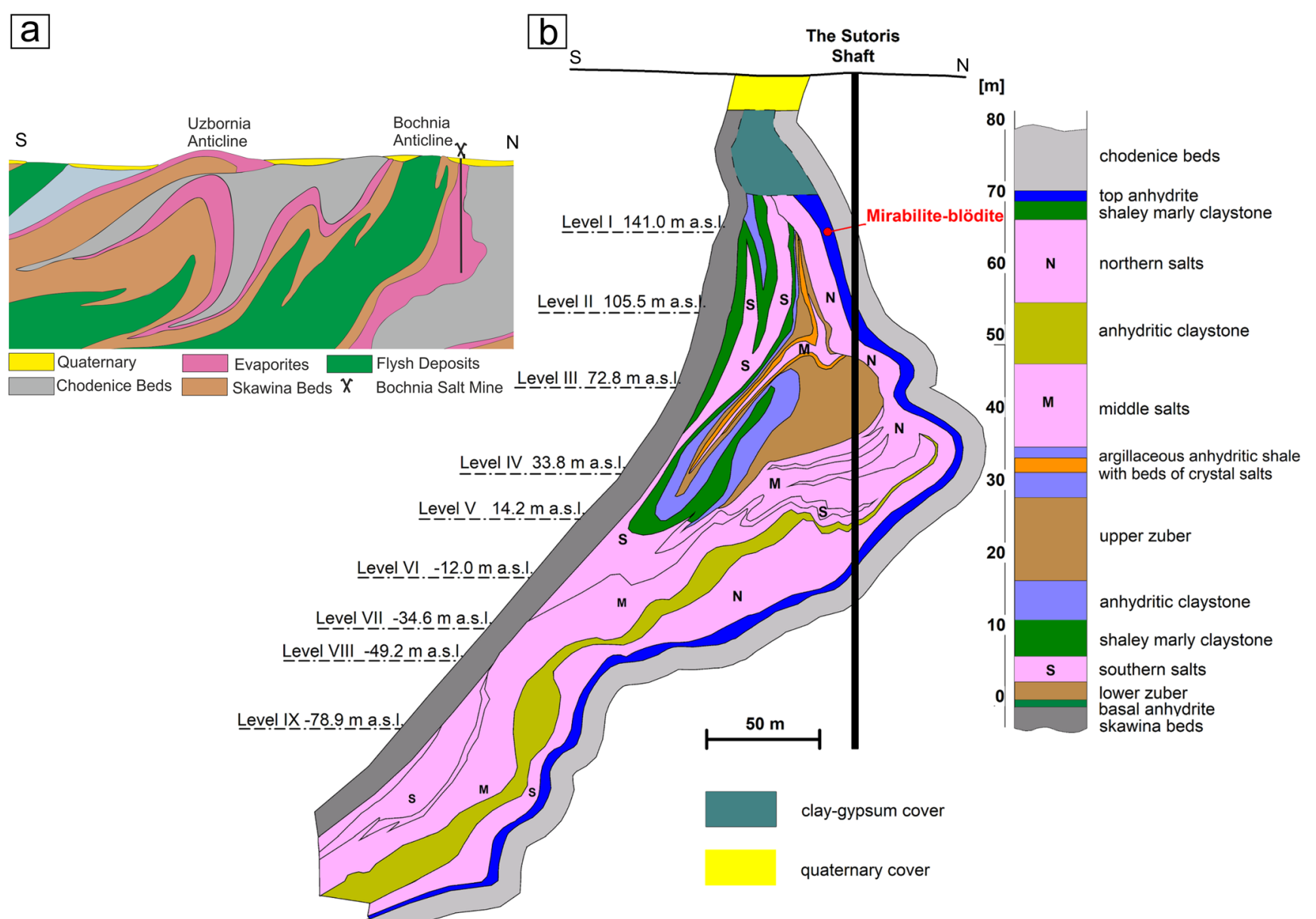

Fig. 4 a Schematic geological cross-section of the Bochnia salt deposit (after Poborski 1952; Garlicki 2008, simplified). b Example of the structure of Bochnia salt deposit shown as a cross-section of the Sutoris shaft (according to Poborski 1952; Wagner et al. 2010, modified) with a lithostratigraphic profile of salt succession (according to Poborski 1952, modified)
Seepage of water is strictly monitored and is observed to be minimal in the excavations of Bochnia Salt Mine. Water penetrates slowly from the Quaternary layers present above, the top anhydrite layer, and the nearby clay-gypsum cap, as well as from the water-permeable zones of the Chodenice and Skawina Beds surrounding the salt deposit. Old operations, abandoned shafts, and remnants of mining activities carried out over hundreds of years might have led to the formation of the conduits which enabled the solutions to penetrate the mostly impermeable rocks. The karst features have been observed locally, in particular within the sulphates in the upper part of the deposit. The total volume of water infiltration into the mine is calculated at approximately $0.45 \mathrm{~m}^{3} / \mathrm{h}$. Mirabilite is found at level I, which is the most waterlogged region. The underground effluents are captured in sumps constructed at the footwall of mine excavations. Crystallisation of the secondary formations is often observed at the spots of seepage, discharge, or dripping, which include the sponge-shaped salt efflorescences, thin salt tubes, coatings, and stalactites (Fig.
5). These formations are mainly composed of sodium chloride (halite), sporadically found associated with sulphates.

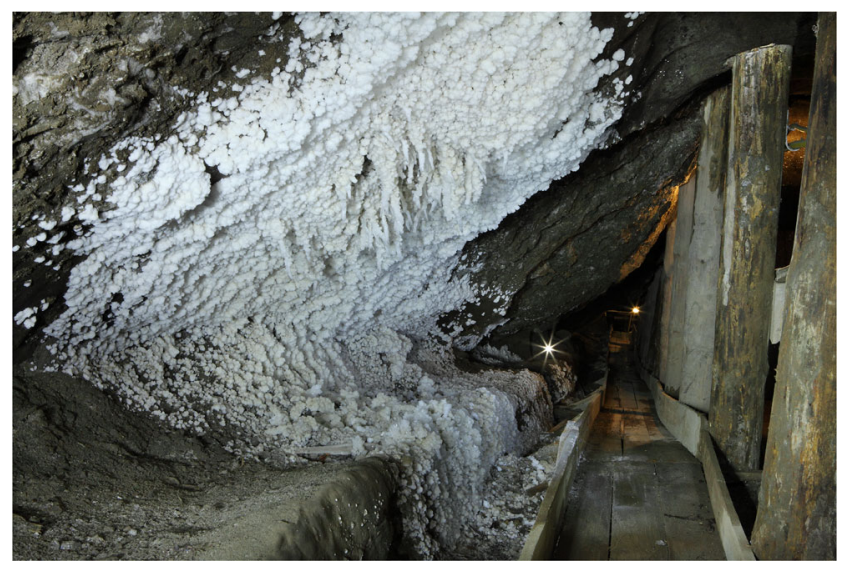

Fig. 5 Attractive halite precipitation associated with occasional underground brine leaks in the Bochnia Salt Mine (photo: Janina Wrzak) 


\section{Characteristics of Mirabilite from Bochnia}

\section{Mirabilite Location}

Among the several dozen leaks and dripstone formations observed in the Bochnia Salt Mine, hydrated sodium sulphates are present in only one formation, which is seen in the eastern part of the mine, near the mediaeval Sutoris shaft at level I (Fig. 4). The Sutoris shaft was deepened during the second half of the thirteenth century, but is still fully operational and in use. The new planned tourist route begins from the descent of the shaft and runs through level I, thus providing an opportunity to present this rare mineral to the visitors.

Mirabilite precipitates locally on the surface of the ceiling at a few square metres, forming small stalactites (up to $15 \mathrm{~cm}$ long) on the steel support present together with timber linings (Fig. 6). The beige-to-brown efflorescences and encrustations are formed of crystals measuring up to $1 \mathrm{~cm}$. The mirabilite mineral is originally white-yellow in colour, and the brown colour is probably imparted by the impurities resulting from the corrosion of the steel support (Sawłowicz et al. 2014). In addition to the important field observations, it was necessary to confirm the occurrence of this unique mineral in the

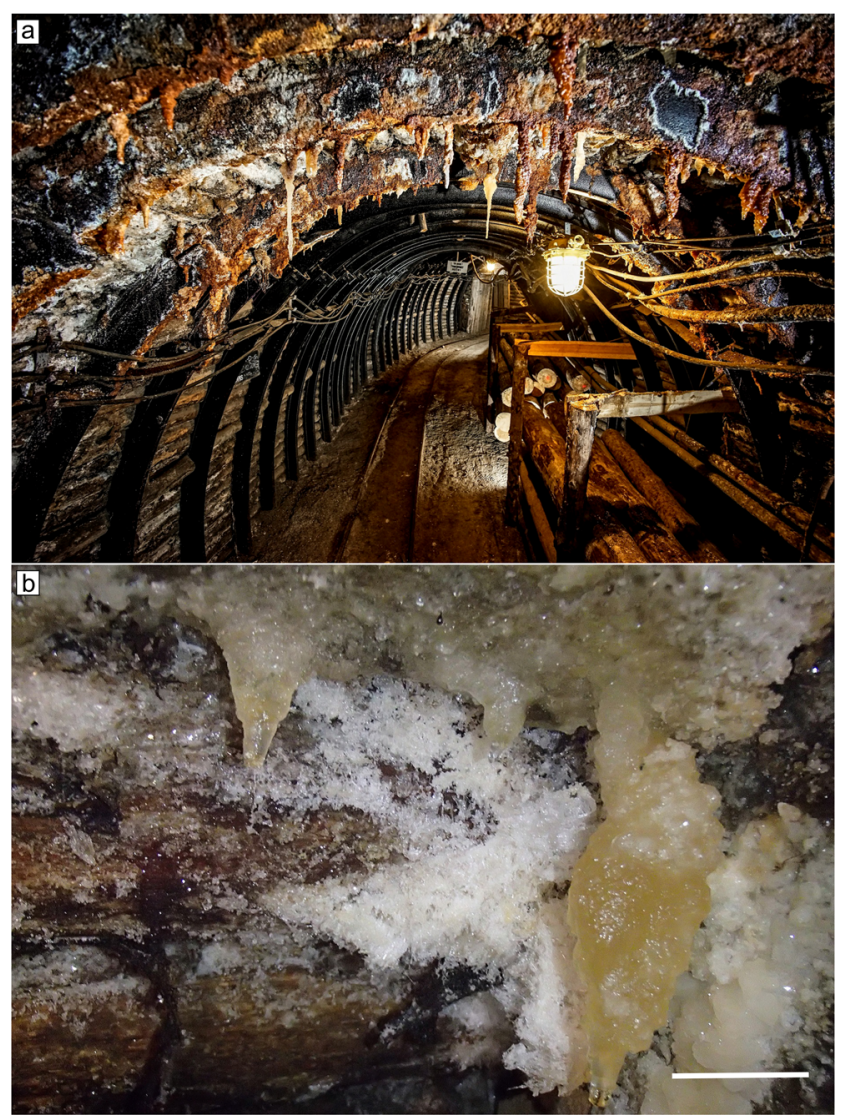

Fig. 6 Sample location. a Mirabilite efflorescence on the steel support found in the form of stalactites and encrustations. b A close-up of mirabilite stalactites (scale bar: $5 \mathrm{~cm}$ ) underground space through sample collection and laboratory analyses.

\section{Sampling Protocol and Analytical Methods}

Mirabilite is a very unstable mineral that quickly dehydrates in dry air transforming into other sulphates (usually as fine crystalline powders) within a few days of its removal from the original location. During sample collection, the air temperature in the mirabilitic site was relatively low $\left(13.6{ }^{\circ} \mathrm{C}\right)$ while the RH was high (74\%). Therefore, special care was taken during the transport and preparation of samples to avoid their exposure to elevated temperatures and dry air. Additionally, to reduce damage to the unique geosite, only two stalactite samples $(5 \mathrm{~cm} \times 3 \mathrm{~cm})$ of distinct colours and one specimen of dry encrustation were collected. The prepared samples were stored in a sealed container at $-5{ }^{\circ} \mathrm{C}$, and laboratory analysis was conducted within $1 \mathrm{~h}$ of storage.

Mineral identification was performed using two methods: X-ray diffraction (XRD) and Raman spectroscopy. To identify the origin of percolating water in mirabilitic site by chemical analysis, water samples were collected from the dripping stalactites of mirabilite (samples D-S) as well as from several other locations of seepage at level I of the mine for comparison. These locations are indicated in Fig. 7. Due to the strong tendency of mirabilite to transition to another mineral phase (thenardite), during changes in the temperature and $\mathrm{RH}$ of the surrounding environment, these climatic parameters were also examined in several locations of the mine. A detailed description of the analytical methods used is listed below.

\section{Description of Analytical Methods}

For mineralogical characterisation, fragments of brown and white stalactites were gently ground in an agate mortar, and the analyses were performed immediately after the specimen was mounted. For the powder XRD procedure, the pulverised sample was covered in an X-ray-transparent foil to minimise its transformation. The diffraction patterns of the sample were recorded with a Rigaku SmartLab diffractometer (NeuIsenburg, Tokyo, Japan), in the $2 \theta$ range of $2-75^{\circ}$ with a step size of $0.05^{\circ}$, using graphite-monochromatized $\mathrm{Cu} \mathrm{K} \alpha$ as a source of radiation. The phases were identified using the ICCD database and XRAYAN software (Marciniak et al. 2006). The composition of both the stalactite samples and water-insoluble fraction (brown stalactite) was analysed.

Raman spectroscopy was performed using a Thermo Scientific DXR Raman microscope. The spectra of the sample were recorded at room temperature using a green laser $(\lambda=$ $532 \mathrm{~nm}$, laser power $=1 \mathrm{~mW}$, slit aperture $=25 \mu \mathrm{m}$, resolution $=1.9 \mathrm{~cm}^{-1}$ in the range between 100 and $3580 \mathrm{~cm}^{-1}$ ). A total of 10 exposures $(3 \mathrm{~s}$ each) were averaged for each spectrum. 
W

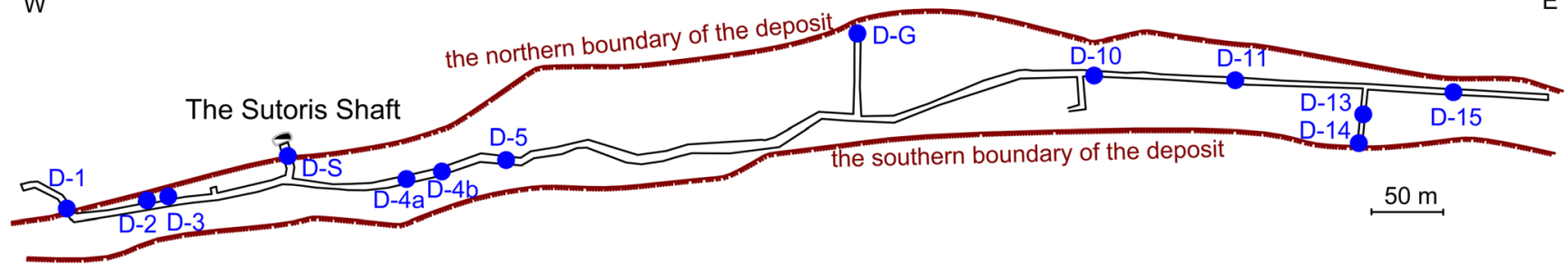

Fig. 7 A simplified sketch of level I with water seepages marked

The spectra were interpreted using the OMNIC for Dispersive Raman software.

Water samples were collected in polyethylene containers and analysed within a few days. The elemental composition of these samples was determined by inductively coupled plasmaoptical emission spectrometry (ICP-OES) using a solid-state detector (ELAN 6100; PerkinElmer).

Air temperature and RH were determined at levels I, III, IV, and $\mathrm{V}$ of the mine, which were in the direct vicinity of the Sutoris shaft, while level II was excluded from the analysis as it does not have any connection with the shaft. All the measurements were taken using an Assmann psychrometer. The measurements were repeated every week for a year (2018). The dry bulb and wet bulb temperatures were recorded to calculate $\mathrm{RH}$, of which the dry bulb temperature represented the air temperature at the study location. Additionally, the temperature and humidity of the site were continuously monitored for a period of 1 week using a portable probe with a data recorder. The obtained values confirmed the absence of short-term fluctuations.

\section{Results and Discussion}

\section{Identification of Mirabilite}

The mineralogical analysis (Fig. 8a) and comparison with the standard patterns indicated that stalactite is composed of crystalline mirabilite $\mathrm{Na}_{2} \mathrm{SO}_{4} \cdot \mathrm{H}_{2} \mathrm{O}$ with a small amount of other minerals. Admixtures of minerals containing iron tint the stalactites to a rusty colour. Additionally, an analysis of the insoluble residue resulting from stalactite dissolution in the water proved the presence of minerals containing Fe and gypsum (Fig. 8b).

The obtained results were further confirmed by microRaman spectroscopy (Fig. 9). The Raman spectrum was found to be almost identical to the standard spectra of mirabilite (Hamilton and Menzies 2010). Spectroscopic analysis was run on the single crystal present at the surface of stalactite, where no other minerals were detected. As expected, mirabilite showed a very similar Raman spectrum as the free sulphate anion in solution. The bands identified at 1677, 3282, and $3441 \mathrm{~cm}^{-1}$ were derived from the water molecules, while the positions of the remaining bands matched the reference values of sodium sulphate in the structure of mirabilite.

\section{Formation of Mirabilite}

Small stalactites found on the ceiling at level I near the Sutoris shaft consist of mirabilite along with other minerals, in a minor amount, which often occur together. This is the only location where mirabilite can be seen in the Bochnia Salt Mine. Thus, the unique geological value of this site was confirmed.

Mirabilite precipitates at a site characterised by a high $\mathrm{RH}$ (between 72 and $88.5 \%$ ) and a constant temperature (between

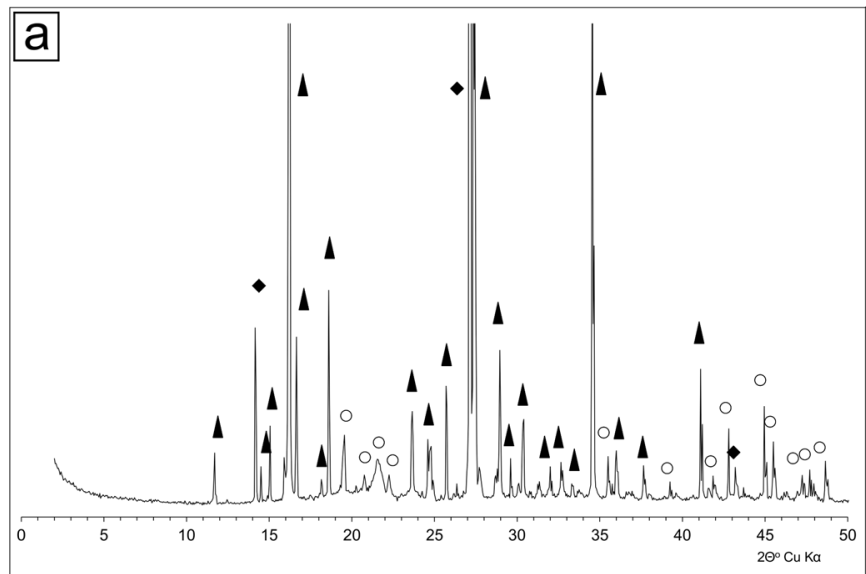

Fig. 8 X-ray diffraction patterns. a Stalactite composed of mirabilite$\mathrm{Na}_{2} \mathrm{SO}_{4} \cdot \mathrm{H}_{2} \mathrm{O}$ (triangles), standard no. 11-0647; blödite$\mathrm{Na}_{2} \mathrm{Mg}\left(\mathrm{SO}_{4}\right)_{2} \cdot 4 \mathrm{H}_{2} \mathrm{O}$ (circles), standard no. 08-0098; lepidocrocite- $\gamma$ -

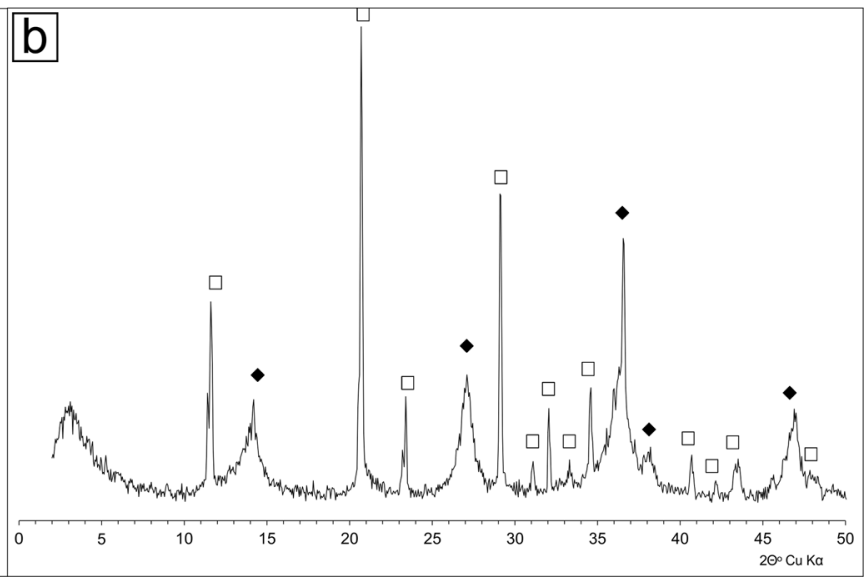

$\mathrm{FeO}(\mathrm{OH})$ (diamonds), standard no. 19-1215. b An insoluble fraction separated from the brown stalactite, composed of gypsum (squares) and lepidocrocite (diamonds) 


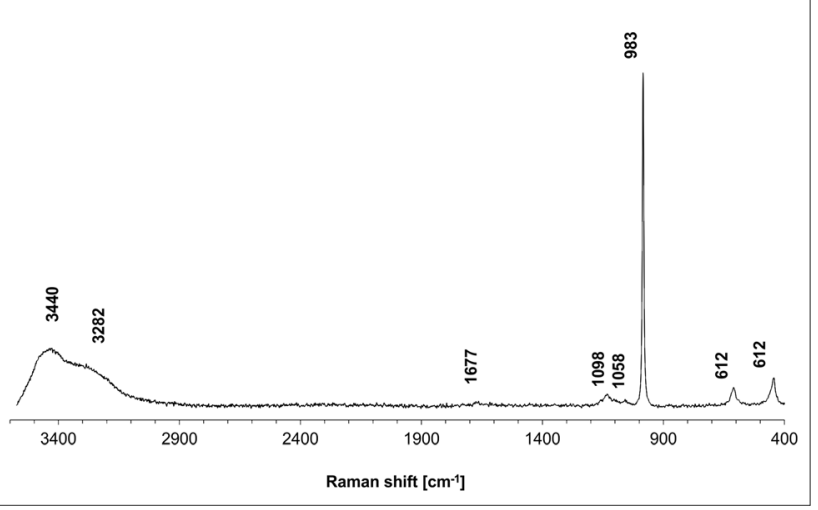

Fig. 9 Raman spectrum of the single crystal apparent on the surface of stalactite: all bands are consistent with those in the spectrum of mirabilite, as reported by Hamilton and Menzies (2010)

13.6 and $14.0^{\circ} \mathrm{C}$ ). The lowest temperature and $\mathrm{RH}$ are observed during the winter season. At most of the other locations in the mine, RH is several percent lower, while the temperature is higher and annual fluctuations are larger $\left(\mathrm{ca} .1^{\circ} \mathrm{C}\right.$ in the case of temperature and $30-40 \%$ for RH; Fig. 10). Therefore, the conditions at this location are favourable for the formation of mirabilite. This area is one of the coldest locations of the mine and has very high humidity. The effect of temperature and humidity on the deliquescence of mirabilite and thenardite is presented by a phase diagram in Fig. 11, in which the annual variations of temperature and humidity at this location are marked by a vertical bar. Despite the fluctuations of these parameters, the climatic conditions at this location favour the formation and stability of mirabilite for the whole year, which is a unique feature of this mine. Moreover, this spot is the most distant from the ventilation shaft that pumps the air from the surface to the mine. During passage through the corridors, the air achieves a constant temperature and characteristic humidity regardless of the surface conditions. These conditions together favour the formation and preservation of mirabilite stalactites in the mine throughout the year.

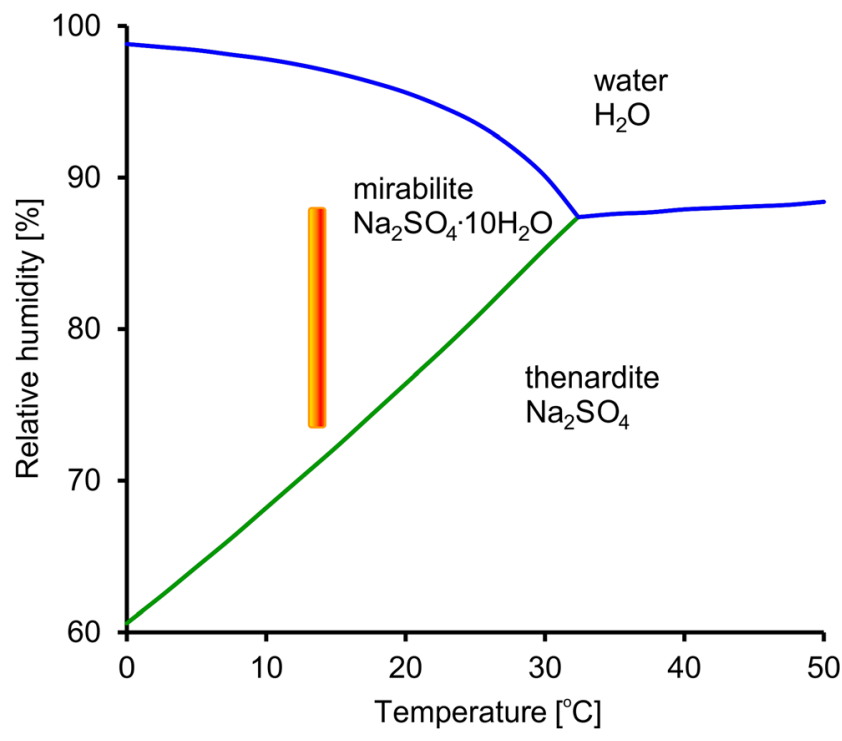

Fig. 11 A simplified phase diagram of the $\mathrm{Na}_{2} \mathrm{SO}_{4}-\mathrm{H}_{2} \mathrm{O}$ system (constructed based on the data presented by Hamilton and Menzies (2010)). The blue line indicates the equilibrium between the mineral phases and the solution. The green line shows the phase equilibrium between mirabilite and thenardite. The vertical orange bar represents the variations in temperature and humidity at the location of mirabilite in the Bochnia Salt Mine

In addition to specific climatic conditions, water leaking at this location is also characterised by unique chemical composition. Compared to the other seepages collected from various locations at level I of the salt mine, water in this location has a significantly higher concentration of $\mathrm{SO}_{4}{ }^{2-}, \mathrm{K}^{+}$, and $\mathrm{Mg}^{2+}$, but a lower concentration of $\mathrm{Ca}^{2+}$ and $\mathrm{HCO}_{3}{ }^{-}$and an acidic $\mathrm{pH}$ (Table 1). The $\mathrm{Mg} / \mathrm{SO}_{4}$ molar ratio of 1 suggested that various sulphates of magnesium and potassium are locally present in the sediments and undergo dissolution in this part of the deposit, and thus, the percolating waters have a unique composition. The $\mathrm{Na} / \mathrm{Cl}$ molar ratio indicated the presence of a small amount of halite which acts as a dominating source of these ions. The mirabilitic site is located next to the thirteenth-
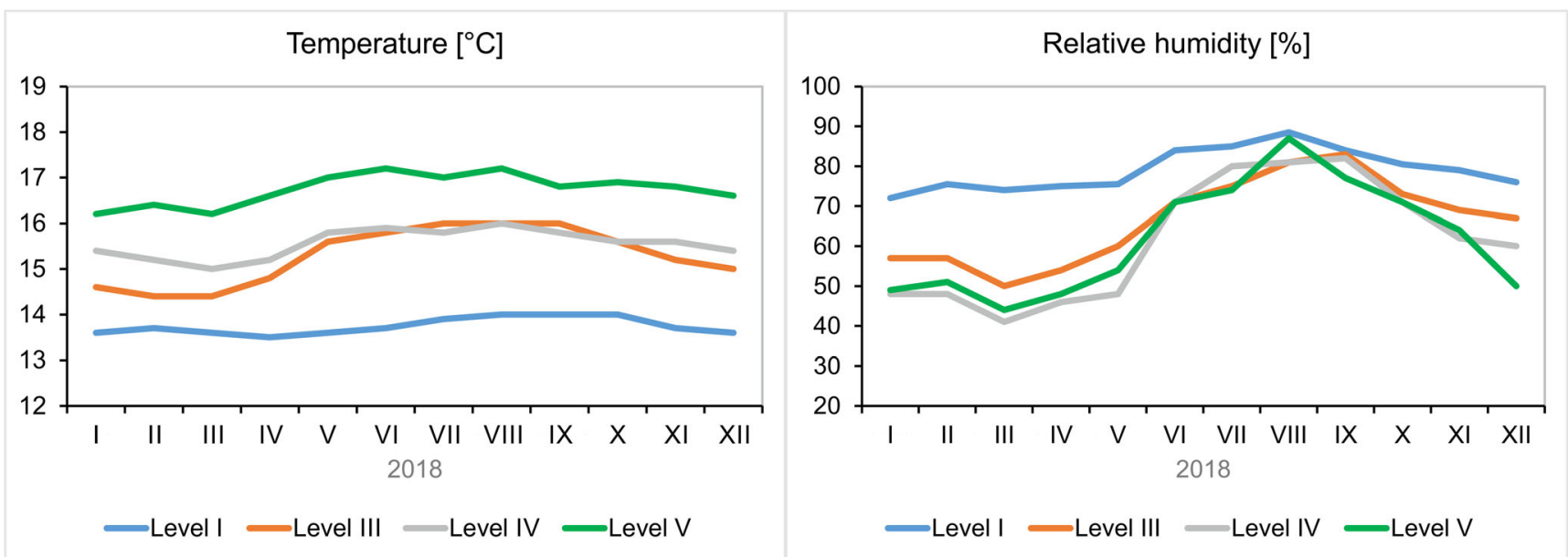

Fig. 10 Average monthly temperature and relative humidity of each of the tested levels 
century Sutoris shaft, which is the oldest in the mine. Mediaeval mining was much different from the one known today - the operation was irregular and carried out from the shaft in various directions. Water infiltration from the surrounding rocks having a relatively low permeability is driven not only by the crevasses or karst of gypsum and anhydrite but also by the network of cracks and discontinuities formed during long-term mining operations. Though these are sealed, the remnants of long-term mining activities may increase the permeability of the rock mass to water in this particular area compared to the other parts of the mine.

To determine the geochemical process contributing to the unique chemical composition of groundwater percolating into the mirabilitic site, hydrochemical modelling of the chemical composition of this water was carried out using the PHREEQC computer code (Parkhurst and Appelo 1999). The modelling results revealed that this solution is close to saturation with respect to not only mirabilite and blödite (saturation index $(\mathrm{SI})=-0.86$ and -2.5 , respectively) but also gypsum $(\mathrm{SI}=-0.2)$, anhydrite $(\mathrm{SI}=-0.3)$, and sulphates of $\mathrm{Na}$ and $\mathrm{Mg}$ (glauberite, $\mathrm{SI}=-0.8$; hexahydrate, $\mathrm{SI}=-1.7$ ), as well as similar evaporite minerals. These suggested that this leakage originates from the top anhydrite layer and the nearby (overlying) secondary cap above the salt deposit, but not from the pure salt. These formations consist mainly of claystone, anhydrite, and gypsum, with hydrated sulphates of $\mathrm{Na}$ and $\mathrm{Mg}$ which often coexist in their vicinity. Thus, hydrochemical modelling confirmed that the major process influencing the chemical composition of water infiltrating into the mirabilitic site is the dissolution of minerals forming the top anhydrite layer and the secondary gypsum cap.

\section{Preservation of Mirabilite Precipitates}

In Poland, the formal protection of abiotic heritage within the existing system of nature conservation is legally regulated by the Nature Conservation Act (2004). The documentary sites are a typical form of protection of underground geological objects. Such legal protection prohibits destroying, damaging, or transforming the protected objects. The legal framework allows for the recognition of the unique mirabilite efflorescence in Bochnia mine as a protected documentary site. However, underground mines are primarily regulated by Geological and Mining Law, which requires, among other things, the use of mining supports for excavations and their periodic replacement depending on the technical condition and safety issues. Based on the results obtained in this study, appropriate practical solutions are proposed as follows for the preservation and protection of mirabilite efflorescence without compromising safety.

1) Maintenance of the mine's current ventilation system. As shown in this report, the long air flow through the corridors favours the formation of mirabilite. Therefore, any large change in the direction of air flow (e.g. a change in the function of the Sutoris shaft from exhaust to inspiratory shaft) will result in the dehydration and deterioration of mirabilite. This is extremely important because the Sutoris shaft previously (until 2004) served as an inspiratory shaft and might possibly be changed again. Due to the fact that some smaller changes in the airflow direction are often necessary to ventilate the newly opened tourist trails and routes, the temperature, $\mathrm{RH}$, and airflow at the mirabilitic site should always be carefully monitored.

Table 1 Composition of the water samples collected from the effluents at level I, Bochnia Salt Mine

\begin{tabular}{|c|c|c|c|c|c|c|c|c|c|c|c|c|c|}
\hline Sample & Sampling location & $\begin{array}{l}\mathrm{Ca}^{2+} \\
\mathrm{mg} / \mathrm{L}\end{array}$ & $\mathrm{Mg}^{2+}$ & $\mathrm{Na}^{+}$ & $\mathrm{K}^{+}$ & $\mathrm{NH}_{4}^{+}$ & $\mathrm{HCO}_{3}^{-}$ & $\mathrm{SO}_{4}{ }^{2-}$ & $\mathrm{Cl}^{-}$ & $\mathrm{pH}$ & TDS & $\begin{array}{l}\mathrm{Na} / \\
\mathrm{Cl}\end{array}$ & $\begin{array}{l}\mathrm{Mg} / \\
\mathrm{SO}_{4}\end{array}$ \\
\hline $\begin{array}{l}\text { Mirabilite } \\
\text { location }\end{array}$ & Dripping stalactite of mirabilite & 410 & 8948 & 48,552 & 1319 & 145 & 67 & 36,558 & 77,968 & 4.8 & 174,308 & 1.0 & 1.0 \\
\hline Sutoris shaft & Shaft lining & 12 & 53 & 17,074 & 308 & 0 & 1594 & 2742 & 22,086 & 9.0 & 44,536 & 1.2 & 0.1 \\
\hline D-1 & Roof and floor & 675 & 158 & 7187 & 133 & 3 & 360 & 4482 & 9853 & 7.0 & 22,857 & 1.1 & 0.1 \\
\hline D-2 & Roof & 648 & 100 & 2985 & 69 & 1 & 326 & 2889 & 3938 & 7.9 & 10,967 & 1.2 & 0.1 \\
\hline D-3 & Roof & 751 & 253 & 10,439 & 114 & 0 & 651 & 4426 & 15,235 & 7.8 & 31,868 & 1.1 & 0.2 \\
\hline D-4a & Floor and sidewall & 1097 & 803 & 89,960 & 444 & 37 & 376 & 3534 & 146,226 & 6.6 & 242,478 & 0.9 & 0.9 \\
\hline D-4b & Floor & 935 & 456 & 90,861 & 282 & 37 & 342 & 6022 & 144,507 & 6.4 & 243,442 & 1.0 & 0.3 \\
\hline D-5 & Floor & 1326 & 295 & 17,586 & 160 & 17 & 1697 & 4154 & 27,569 & 7.0 & 52,816 & 1.0 & 0.3 \\
\hline D-G & Floor & 706 & 704 & 113,008 & 413 & 105 & 94 & 4764 & 179,769 & 7.2 & 299,574 & 1.0 & 0.6 \\
\hline D-10 & Floor & 710 & 552 & 104,902 & 209 & 55 & 152 & 4561 & 167,987 & 7.4 & 279,127 & 1.0 & 0.5 \\
\hline D-11 & Floor & 733 & 553 & 110,861 & 186 & 40 & 190 & 4518 & 177,331 & 7.3 & 294,413 & 1.0 & 0.5 \\
\hline D-13 & Roof & 636 & 371 & 99,937 & 156 & 34 & 364 & 5482 & 157,826 & 7.1 & 264,807 & 1.0 & 0.3 \\
\hline D-B & Floor & 832 & 451 & 104,431 & 252 & 50 & 233 & 4878 & 164,466 & 7.2 & 275,594 & 1.0 & 0.4 \\
\hline D-15 & Roof and floor & 557 & 808 & 95,115 & 413 & 75 & 298 & 9005 & 150,112 & 7.6 & 256,383 & 1.0 & 0.4 \\
\hline
\end{tabular}


2) Exclusion of the mirabilitic zone from the rock mass sealing. The presence of seepage solutions is another essential factor for mirabilite crystallisation. However, penetration of water into the underground salt mine may have a destructive effect on the stability of rock mass. Lower salinity of the leaks causes uncontrolled dissolution of the salt layers, which in turn may damage the rock mass. Therefore, to stop the seepage, the rocks must be sealed sometimes by filling the gaps in the rock mass with waterproof products, creating a watertight barrier. Fortunately, the amount of solutions seeping at the mirabilite site is very small (a few drops per minute) and stable over time and thus does not pose a risk. Moreover, this leakage comes from the upper layers of the anhydrite and the secondary cover, not from the salt layers, as evidenced by its chemical composition. However, incorrect reinforcement and sealing of the rock mass in close proximity to the mirabilite exposure would interfere with the natural crystallisation of this rare mineral. Therefore, the narrow mirabilitic zone should be excluded from works to protect against the influx of poorly mineralised waters. For safety reasons, it is important to periodically check the count of mirabilite stalactite droplets and perform chemical analysis.

3) Replacing the mine casing with special care. Any replacement of the mine supports in the location of mirabilite may result in its destruction. Therefore, it is necessary to develop a compromise approach, considering the legal requirements in the field of mining, which would allow carrying out repair works while maintaining the unique and valuable geological phenomena, in this case mirabilite crystallisation. Replacement of supports should not interfere much with the structure of the rock mass to preserve the existing water circulation. This would allow mirabilite to crystallise again on the new support. It is very difficult to predict the scale of future mining works in such a protected area, but if possible, only the most damaged part of the support should be replaced. To ensure proper protection, the changes must be monitored and recorded.

\section{Potential for Geotourism Development}

The new planned route run through level I, providing an excellent opportunity to present this rare mineral to the visitors and thus serving the actual purpose of including the geological processes to a large extent. As the new routes will pass through the mirabilitic site, the inclusion of this point in the programme would not incur high costs in the planned budget. Moreover, these route is designed to include elements of an interactive exhibition, for more accessible visualisation of data.

So far, the sites of high geological value were marked by an information board explaining their geological features via photographs, sketches, profiles, and comprehensive descriptions. However, such a presentation of the complex geology of salt deposit might be understandable by specialists in the field of geology. For a broad audience, including nature fascinators, it can be unclear and unattractive. Therefore, to improve the interpretation of geoheritage, the information should be presented in a more appropriate manner to non-professionals. In recent years, digital technologies have been proven to be very useful in the efficient representation of geological phenomena and for communicating the scientific outcomes to a large number of tourists (Martin 2014; Santos et al. 2018; Melelli 2019).

Nevertheless, the introduction of certain modern technologies (multimedia presentations, strong lighting, etc.) to the underground mirabilitic site may pose a threat to its microclimatic balance (e.g. heat emission). Therefore, the use of boards remains the only appropriate option for presenting the information. To ensure that the output is clear enough to the public, only the essential features of mirabilite formation should be presented. These include the current location of mirabilite within the geological structure of the salt deposit and within the underground excavation network, as well as the specific path of brine percolation from this part of the deposit through the network of cracks and discontinuities formed during long-term mining operations. In addition, it is very important to regulate the number of sightseers and the time of their stay in the mirabilitic site, since intensive tourist flow can also significantly change the temperature and $\mathrm{RH}$ in the mine (Alexandrowicz 2000). This is also a key factor determining the appropriate amount of information about mirabilite to be presented to the tourists.

However, some ideas on information presentation on the board can be provided. A great amount of geological, mineralogical, and chemical data collected in this study could be extremely useful in digitalizing the process of mirabilite formation and this phenomenon within the overall geological and historical context of the Bochnia Salt Mine. Threedimensional images can be more easily and rapidly assimilated than two-dimensional ones (sketches or maps) and are thus more suitable for the non-specialist public (Lansigu et al. 2014). The imagery should be designed to convey as much visually appealing information as possible, with minimum text where it is absolutely necessary. Some exemplary panels with the division of the space can be found in the literature (Venturini and Pasquaré Mariotto 2019). The imagery should be supported by a chronological explanation by guides. Thus, it is also very important to develop a training programme for employees and tourist guides for them to build a narrative about mirabilite. Additionally, because of frequent visits by students and professional geologists, installation of a special information board is highly recommended similar to other geosites in the mine.

Since the new route starts in the Sutoris shaft pithead, the visitors must be provided with some basic knowledge about the geology of the area before they descend the mine and reach the mirabilite exhibition. This allows more possibilities to 
arrange the exhibition using a digital tool than in the underground space.

\section{Conclusions}

The present work confirmed the occurrence of mirabilite, a relatively rare mineral $\left(\mathrm{Na}_{2} \mathrm{SO}_{4} \cdot 10 \mathrm{H}_{2} \mathrm{O}\right)$, in the Bochnia Salt Mine. The mineral forms contemporary precipitates as small stalactites and occurs together with blödite $\left(\mathrm{Na}_{2} \mathrm{Mg}\left(\mathrm{SO}_{4}\right)_{2} \cdot 4 \mathrm{H}_{2} \mathrm{O}\right)$. Its unique presence in only one location in this old underground salt mine is attributed to contemporary precipitation from percolating solutions, caused by the combination of at least two factors:

- the specific chemical composition of the brine leaking from this part of the deposit (or from the remains of old excavations), and

- the specific and stable microclimate characterised by a low temperature, high humidity, and relatively strong air circulation which accelerates evaporation and crystallisation.

The unique geological and educational value of this geosite indicates the need for its preservation. However, although the mirabilite efflorescence may be brought under legal protection within the existing system of nature conservation, the unstable nature of this mineral demands unconventional efforts for the conservation, preservation, and public access of this geosite. Appropriate solutions that can be practically applied for the preservation and protection of mirabilite efflorescence include maintenance of the mine's current ventilation system, exclusion of the mirabilitic zone from the rock mass sealing, and replacing the mine casing with special care in case of repairs. With certain precautions to ensure the protection of the mirabilite environment, the new tourist routes will allow presenting this intriguing mineral to a wider audience. The presence of mirabilite, with appropriate protection, can be another geological attraction for tourists and students visiting this thirteenth-century UNESCO-recognised salt mine.

Acknowledgements We would like to thank all the personnel of the Bochnia Salt Mine for their great technical support and assistance. We thank the two anonymous reviewers whose suggestions helped improve this manuscript.

\section{Availability of Data and Material Not applicable}

\section{Code Availability Not applicable}

Funding Financial support for the research was provided by Polish Ministry of Science and Higher Education grant no. 30/DW/2017/01/1 under "Implementation Doctorates" programme.

\section{Declarations}

Competing Interests The authors declare no competing interests.
Open Access This article is licensed under a Creative Commons Attribution 4.0 International License, which permits use, sharing, adaptation, distribution and reproduction in any medium or format, as long as you give appropriate credit to the original author(s) and the source, provide a link to the Creative Commons licence, and indicate if changes were made. The images or other third party material in this article are included in the article's Creative Commons licence, unless indicated otherwise in a credit line to the material. If material is not included in the article's Creative Commons licence and your intended use is not permitted by statutory regulation or exceeds the permitted use, you will need to obtain permission directly from the copyright holder. To view a copy of this licence, visit http://creativecommons.org/licenses/by/4.0/.

\section{References}

Alexandrowicz Z (ed) (2000) Crystal caves in the Wieliczka Salt Mine (in Polish with English summary). Studia Naturae 46:11-18

Alexandrowicz Z, Alexandrowicz SW (2004) Geoparks-the most valuable landscape parks in southern Poland. Polish Geological Institute Special Papers 13:49-56

Alexandrowicz Z, Miśkiewicz K (2016) Geopark - od idei do realizacji, ze szczególnym uwzględnieniem Polski (Engl. summ. Geopark from the concept to implementation, with special reference to Poland). Chrońmy Przyr Ojcz 72(4):243-253

Alexandrowicz Z, Urban J, Miśkiewicz K (2009) Geological values of selected Polish properties of the UNESCO World Heritage List. Geoheritage 1:43-52. https://doi.org/10.1007/s12371-009-0004-y

Bieniok A, Zagler G, Brendel U, Neubauer F (2011) Speleothems in the dry Cave Parts of the Gamslöcher-Kolowrat Cave, Untersberg near Salzburg (Austria). Int J Speleol 40:117-124. https://doi.org/10. 5038/1827-806X.40.2.4

Bridge P (1973) Guano minerals from Murra-el-elevyn Cave Western Australia. Mineral Mag 39(304):467-469. https://doi.org/10.1180/ minmag.1973.039.304.10

Cabestrero Ó, del Buey P, Sanz-Montero ME (2018) Biosedimentary and geochemical constraints on the precipitation of mineral crusts in shallow sulphate lakes. Sediment Geol 366:32-46. https://doi.org/ 10.1016/j.sedgeo.2018.01.005

Crétaux JF, Létolle R, Calmant S (2009) Investigations on Aral Sea regressions from mirabilite deposits and remote sensing. Aquat Geochem 15:277291-277291. https://doi.org/10.1007/s10498-0089051-2

d'Obyrn K (2012) The analysis of destructive water infiltration into the Wieliczka Salt Mine-a unique UNESCO site. Geological Quarterly 56:85-94

Dalton JB III, Pitman KM (2012) Low temperature optical constants of some hydrated sulfates relevant to planetary surfaces. J Geophys Res 117(E09001). https://doi.org/10.1029/2011JE004036

De Waele J, Carbone C, Sanna L, Vattano M, Galli E, Sauro F, Forti P (2017) Secondary minerals from salt caves in the Atacama Desert (Chile): a hyperarid and hypersaline environment with potential analogies to the Martian subsurface. Int J Speleol 46(1):51-66. https://doi.org/10.5038/1827-806X.46.1.2094

Dudek K, Kicińska A, Rybowicz P,Wiewiórka J (2014) Secondary evaporite minerals from the historic Bochnia Salt Mine. Mineralogia special papers 42

Forti P (2017) Chemical deposits in evaporite caves: an overview. Int J Speleol 46(2):109-135. https://doi.org/10.5038/1827-806X.46.2.2063

Garlicki A (1979) Sedimentation of Miocene Salts in Poland. Prace Geologiczne PAN 119:1-67 (in Polish with English summary)

Garlicki A (2008) Salt mines at Bochnia and Wieliczka. Prz Geol 56(8/1): 663-669 
Garofano M, Govoni D (2012) Underground geotourism: a historic and economic overview of show caves and show mines in Italy. Geoheritage 4:79-92. https://doi.org/10.1007/s12371-012-0055-3

Głowacki W (2019) Newly emerging geosites in the Polish Western Outer Carpathians as an asset for geoeducation and geotourism. Geoheritage 11:1247-1256. https://doi.org/10.1007/s12371-019-00415-9

Gordon JE (2018) Geoheritage, geotourism and the cultural landscape: enhancing the visitor experience and promoting geoconservation. Geosciences 8:136. https://doi.org/10.3390/geosciences8040136

Hamilton A, Menzies RI (2010) Raman spectra of mirabilite, $\mathrm{Na}_{2} \mathrm{SO}_{4} \cdot 10 \mathrm{H}_{2} \mathrm{O}$ and the rediscovered metastable heptahydrate, $\mathrm{Na}_{2} \mathrm{SO}_{4} \cdot 7 \mathrm{H}_{2} \mathrm{O}$. J Raman Spectrosc 41:1014-1020. https://doi.org/ $10.1002 / \mathrm{jrs} .2547 \mathrm{~J}$

Hellqvist M (2019) Teaching sustainability in Geoscience field education at Falun Mine World Heritage site in Sweden. Geoheritage 11: 1785-1798. https://doi.org/10.1007/s12371-019-00387-w

Herrero MJ, Escavy JI, Schreiber BC (2015) Thenardite after mirabilite deposits as a cool climate indicator in the geological record: lower Miocene of central Spain. Clim Past 11:1-13. https://doi.org/10. 5194/cp-11-1-2015

Kelley LI, Holmden C (2001) Reconnaissance hydrogeochemistry of economic deposits of sodium sulfate (mirabilite) in saline lakes, Saskatchewan, Canada. Hydrobiologia 466:279-289. https://doi. org/10.1023/A:1014565619506

Kennedy MC, Watson PJ (1997) The chronology of early agriculture and intensive mineral mining in the Salts Cave and Mammoth Cave Region, Mammoth Cave National Park, Kentucky. J Cave Karst Stud 59:5-9

Lansigu C, Bosse-Lansigu V, Le Hebel F (2014) Tools and methods used to represent geological processes and geosites: graphic and animated media as a means to popularize the scientific content and value of geoheritage. Geoheritage 6(2):159-168. https://doi.org/10.1007/ s12371-014-0101-4

Liso IS, Chieco M, Fiore A, Pisano L, Parise M (2020) Underground geosites and caving speleotourism: some considerations, from a case study in southern Italy. Geoheritage 12:13. https://doi.org/10.1007/ s12371-020-00424-z

Liu T, Bish D, Socki R, Harvey R, Tonui E (2015) Mineralogy and formation of evaporite deposits from the Lewis Cliff ice tongue, Antarctica. Antarct Sci 27:73-84. https://doi.org/10.1017/ S0954102014000406

López-García JA, Oyarzun R, López Andrés S, Manteca Martínez JI (2011) Scientific, educational, and environmental considerations regarding mine sites and geoheritage: a perspective from SE Spain. Geoheritage 3:267-275. https://doi.org/10.1007/s12371-011-0040-2

Madziarz M (2013) Opportunities of making post-mining objects in Bystrzyca Górna area in Lower Silesia available for tourists. CUPRUM Czasopismo Naukowo-Techniczne Górnictwa Rud 3(68):77-84

Marciniak H, Diduszko R, Kozak M (2006) XRAYAN-Program do rentgenowskiej analizy fazowej. KOMA Warszawa (in Polish)

Marszałek M, Dudek K, Gaweł A, Czerny J (2019) Mineralogical and geochemical studies of secondary mineral assemblages related to deterioration of building materials. Geological Quarterly 63(4): 683-698. https://doi.org/10.7306/gq.1494

Martin S (2014) Interactive visual media for geomorphological heritage interpretation. Theoretical Approach and Examples. Geoheritage 6(2):149-157. https://doi.org/10.1007/s12371-014-0107-y

Melelli L (2019) "Perugia Upside-Down": a multimedia exhibition in Umbria (Central Italy) for improving geoheritage and geotourism in urban areas. Resources 8(3):148. https://doi.org/10.3390/ resources 8030148
Ortí F, Gündogan I, Helvaci C (2002) Sodium sulphate deposits of Neogene age: the Kirmir Formation, Beypazari Basin, Turkey. Sediment Geol 146:305-333. https://doi.org/10.1016/S00370738(01)00140-3

Parkhurst DL, Appelo CAJ (1999) User's guide to PHREEQC (Version 2): a computer program for speciation, batch-reaction, one-dimensional transport, and inverse geochemical calculations. Water-resources investigations report, Report 99-4259. Denver, Co, USA, p 312

Peryt TM (2013) Palaeogeographical zonation of gypsum facies: Middle Miocene Badenian of Central Paratethys (Carpathian Foredeep in Europe). J Palaeogeogr 2(3):225-237. https://doi.org/10.3724/SP.J. 1261.2013 .00028

Poborski J (1952) The Bochnia salt deposit on the geological background of region. Biuletyn Państwowego Instytutu Geologicznego 78:3160 (in Polish with English summary)

Puławska A, Manecki M, Flasza M, Styszko K (2021) Origin, distribution, and perspective health benefits of particulate matter in the air of underground salt mine: a case study from Bochnia, Poland. Environ Geochem Health. https://doi.org/10.1007/s10653-021-00832-2

Rapin W, Ehlmann BL, Dromart G, Schieber J, Thomas NH, Fischer WW, Fox VK, Stein NT, Nachon M, Clark BC, Kah LC, Thompson L, Meyer HA, Gabriel TSJ, Hardgrove C, Mangold N, Rivera-Hernandez F, Wiens RC, Vasavada AR (2019) An interval of high salinity in ancient Gale crater lake on Mars. Nat Geosci 12: 889-895. https://doi.org/10.1038/s41561-019-0458-8

Ruiz-Agudo E, Mees F, Jacobs P, Rodriguez-Navarro C (2007) The role of saline solution properties on porous limestone salt weathering by magnesium and sodium sulphates. Environ Geol 52:269-281. https://doi.org/10.1007/s00254-006-0476-x

Santos I, Henriques R, Gorki M, Pereira DI (2018) Methodologies to represent and promote the geoheritage using unmanned aerial vehicles, multimedia technologies, and augmented reality. Geoheritage 10(2):143-155. https://doi.org/10.1007/s12371-018-0305-0

Sawłowicz Z, Przybyło J, Boroń K (2014) Colourful speleothems in the Wieliczka Salt Mine. Geological Quarterly 58(3):449-458. https:// doi.org/10.7306/gq.1155

UNESCO (2013) World Heritage List. Wieliczka and Bochnia Royal Salt Mines. Available at https://whc.unesco.org/en/list/32/. Accessed 30 June 2020

Valero-Garcés BL, González-Sampériz P, Delgado-Huertas A, Navas A, Machín J, Kelts K (2000) Lateglacial and Late Holocene environmental and vegetational change in Salada Mediana, central Ebro Basin, Spain. Quat Int 73(74):29-46. https://doi.org/10.1016/ S1040-6182(00)00063-X

Vaniman DT, Bish DL, Chipera SJ, Fialips CI, Carey JW, Feldman WC (2004) Magnesium sulphate salts and the history of water on Mars. Nature 431:663-665. https://doi.org/10.1038/nature02973

Venturini C, Pasquaré Mariotto F (2019) Geoheritage promotion through an interactive exhibition: a case study from the Carnic Alps, NE Italy. Geoheritage 11:459-469. https://doi.org/10.1007/s12371018-0299-7

Wagner M, Bukowski K, Stochel B (2010) Petrological character of lignite (brown coal) from Badenian salts in the Bochnia Mine (Southern Poland). Geological Quarterly 54:439-448

Wiewiórka J (1971) Wtórny mirabilit z Wieliczki (Secondary mirabilite from Wieliczka). Sprawozdanie z Posiedzenia Komisji PAN Odział w Krakowie (in Polish)

Wiewiórka J, Charkot J, Dudek K, Gonera M (2008) Historic salt mines in Wieliczka and Bochnia. Geotourism/Geoturystyka 4(18):61-70

Wiewiórka J, Dudek K, Charkot J, Gonera M (2009) Natural and historic heritage of the Bochnia salt mine (South Poland). Studia Universitatis BabeșBolyai, Geologia 54(1):43-47. https://doi.org/ 10.5038/1937-8602.54.1.9 